\title{
TRANSPORTATION MODAL CHOICE IN COOLANT IMPORTATION THROUGH TOTAL COSTS MINIMIZATION: A CASE STUDY
}

\author{
Marcela de Souza Leite \\ Federal Institute of São Paulo - Suzano Campus, Brazil \\ E-mail: marcelaleiteengenheira@gmail.com \\ Stephanie Conceição Santos \\ Federal Institute of São Paulo - Suzano Campus, Brazil \\ E-mail: stephaniesan_09@hotmail.com \\ Wagner Roberto Garo Junior \\ Federal Institute of São Paulo - Suzano Campus, Brazil \\ E-mail: wagner.garo@ifsp.edu.br \\ Submission: $31 / 03 / 2016$ \\ Accept: $31 / 03 / 2016$
}

\section{ABSTRACT}

Transportation plays a very significant role when it comes to the costs of a company representing on average $60 \%$ of logistics costs, so its management is very important for any company. The transportation modal choice is one of the most important transportation decisions. The purpose of this article is to select the transportation mode which is able to minimize total costs, and consistent with the objectives of customer service on the coolant import, which is used in plasma cutting machines. With the installation of a distribution center in Brazil and the professionalization of the logistics department of the company, it was decided to re-evaluate the transportation mode previously chosen to import some items. To determine the best mode of transportation was used basic compensation costs, in other words the cost compensation of using the shuttle service to the indirect cost of inventory related to the modal performance. Through the study, it was possible to observe it may be possible to save up to $73 \%$ on the coolant international transportation by changing the transportation mode used by the company. 
Keywords: Modal, Ocean Transportation, Air transportation, Cost Reduction, Import.

\section{INTRODUCTION}

The transportation in the national or international level is regarded as one of the most important Logistics sub-process. It involves the external displacement of the supplier to the company, between plants and the company to the customer, being in material forms, components, sub-assemblies, semi-finished products, finished products or spare parts. In this way, the physical transfer (national or international) that takes place in these sectoral transactions requires some means of transportation.

Although the transportation decisions are expressed in a variety of ways, the most important are: the modal selection, the routing conveyor, to program vehicles and consolidation shipment. So there are many ways to carry a product and several available modes, so the companies rarely use only one way to carry their products.

The air transportation mode is fast and eliminates the need for large inventories in transit, source and destination; but it is expensive. On the other side shipping is slow, and so it is necessary higher stocks to cover both delays of uncertainty and materials transit time.

The purpose of this article is, through a case study, identify and select the transportation mode that presents the lowest total cost, and also that is compatible with the customer's needs in coolant import process for plasma cutting machines.

The case study was carried out in a medium-sized company that sells metal cutting machines (machines with plasma, laser and water jet technology) and their spare parts and accessories. All its products are manufactured in the United States and the company distributes them to countries on five continents, via local offices and central warehouses installed in some countries or directly from the United States.

The analyzed product is a liquid used for cooling the torches (piece by which the plasma comes out to make the cut in metals) of mechanized plasma cutting machines.

This study originates from the definition of the following problem: what is the most advantageous mode of transportation to import coolants? Besides, it will 
DOI: $10.14807 /$ ijmp.v7i5.459

consider two types of modes, air and sea. Both are used by the company studied the import coolant from the US to Brazil.

Currently the company uses air mode of transportation to import the coolant from the US. This decision was made since the beginning of the company's operations in Brazil (in 2003) when the company did not have a distribution center (DC) in this country. However, in 2012, a CD was installed in the city of Cajamar, state of São Paulo.

This article is divided into five sections, including this introduction. The second section presents the literature review of the issues addressed in this paper. In the third section the method used in the research. The fourth section presents the results and discussions. Finally, in the fifth section, the research final considerations are reported.

\section{LITERATURE REVISION}

\subsection{Transportation decisions and the modal selection}

To Alvarenga and Novaes (2004) although the logistics encompasses several items, such as inventory management, marketing, processing and marketing information, the subsystem transportation is one of the most important logistical items, it includes variables related to level of service and It has a great impact on operating costs.

According to Caixeta-Son and Gameiro (2001), transportation is usually the main logistics component and most often is seen as the last frontier for reducing costs in companies. However, optimization of this link may reduce the power of regional monopolies and allow the service to customers who do not consume products, price conditions or availability at point of sale.

The main transportation objective is to move products from one source location to a destination while minimizing the financial, temporal and environmental costs. The costs of damages should also be minimized. At the same time, the drive must meet customer expectations regarding the performance of deliveries and availability of information on cargo transported (BOWERSOX ; CLOSS , 2001).

For Rodrigues (2007) a transportation system is constituted by mode ( transportation path), the form (the relationship between the various modes), the 
DOI: $10.14807 /$ ijmp.v7i5.459

medium (carrier element) and the additional installations (load terminals). However, Silva and Porto (2003) rank as the transportation mode as land (road, rail and pipeline), water transportation (maritime and waterway) and air.

According to Faria and Costa (2010) the choice of transportation mode is influenced by cost factors, the origin transit time destination, risk (involving cargo integrity) and frequency (regular shipping). Normally, the cost factor is the most important in economic and financial terms, but other factors may also compromise the definition of the transportation mode and is related to the achievement of the required service level.

For Chopra and Meindl (2003) to choose the means of transportation the shipper must balance transportation costs and inventory. The most cost-effective means of transportation must not necessarily reduce total costs. The cheap transportation typically have longer lead times and higher minimum amount of delivery, both leading to higher stock levels. The means of delivery in small quantities decrease inventory levels, but tend to be more expensive. He reports that Dell ships most of its components from Asia by air freight and the choice can be justified because the use of faster means of transportation for sending high-value components allows Dell to maintain low inventory levels.

Chow (2008) shows an example that shows the resulting conflict between the timing of transportation and permanence of inventories. Imports from East Asia used to reach North America through ports on the west coast and were heading east by rail and road transportation. The increase in fuel prices raised the cost of land transportation and caused many imports began to enter into the East Coast, sea transit via Panama and Suez Canal. This maneuver has extended the stay and the cost of inventories, but made it possible to reduce the shipping cost.

Lorandi, Bertan and Ferreira (2011) in a case study on a consumer electronics company found that logistics costs involved in acquiring an imported product, via air freight is higher than the sea, but that the possibility of providing the goods in shortest time is a viable trade-off.

According to Faria and Costa (2010) the national or international transportation can be accomplished by the following modes: road, rail, air transportation, pipeline and water transportation (maritime, fluvial and lacustrine). In 
DOI: 10.14807/ijmp.v7i5.459

this study we will only cover the modes of air and water transportation (marine) due to the distance and accessibility between the United States and Brazil.

International shipping is dominated by ocean carriers that handle more than $50 \%$ of trading volume in dollars and $99 \%$ by weight. Air carriers moving $21 \%$ of the trade volume in dollars and the remainder is transported by road, rail and pipeline between neighboring countries. (Ballou, 2006).

As reported by the Center for Research on Regional Economics (Ceper) in 2014 the main means of transportation used both for input and for output of products from Brazil's maritime representing $75.1 \%$ of imports. The second major modal used for imports is the air that is used to transportation lower product volume and increased value, perishable foods and pharmaceuticals with shorter period of validity, representing $17.8 \%$ of imports.

According to Chopra and Meindl (2003) by the quantities shipped and the distance traveled, the water transportation is the cheapest for international trade. Delays in ports, customs and management of containers are the main concerns in international shipments by this means. For Bowersox and Closs (2001) the main advantage of water transportation is the ability to move very heavy loads. This type of transportation uses two types of boats: the high seas that are designed for use in oceans and large lakes and barges that usually operate in rivers and canals. The ability of maritime and inland waterways have to carry large volumes/tonnages to a variable low cost makes this mode of transportation is required when you want to get low freight rates and when speed is secondary issue.

According to Faria and Costa (2010) the waterway mode does not present flexibility of routes and terminals and depends on solution as intermodal and relevant legislation to processing in bonded warehouses. For Ballou (2006) claims involving the transportation of high value are much greater in shipping and required additional packaging to protect the goods mainly against rough handling during loading and unloading operations.

Air transportation is one of the sectors that are often identified as strategic by both governments and industry analysts. This qualification is due to the great enhancement factor for entering the country in the international context and to strengthen its geopolitical positions and trade ties (SALGADO et al, 2010). According 
DOI: 10.14807/ijmp.v7i5.459

to Aguiar (2011) the speed that aviation brings to transportation attracts more and more sectors of the economy.

According to Ballou (2006) that speed is not directly comparable with other modes of transportation for the time of collection and delivery of ground handling are not included and all these time elements must be combined to represent the port of delivery time the door.

Besides carrying cargo with much higher speed to the other modes, air transportation has lower levels of damage and loss, resulting in greater safety and reliability. For this reason, not only of high added value products such as electronics and precision instruments, are transported by plane, as well as a number of products sensitive to weathering, such as perishable foods, flowers, orders, etc. (Novaes, 2007). For Bowersox and Closs (2001) the speed of air travel allows other logistical benefits such as the reduction or elimination of operating warehouses and inventories.

For Faria and Costa (2010) the modal air transportation should be chosen for medium and long distances, in the case of products with high added value and high level of demand as service levels to customers. The author also reports that for this mode of transportation insurance costs and packaging are lower due to lower transit time.

According to Chopra and Meindl (2003) air carriers offer a considerably expensive means of transportation. He reports that due to the growth of high technology, the freight weight carried by air has been reduced over the last two decades of the twentieth century while the amount of freight increased. According to Ballou (2006) the air transportation rates are twice those of road transportation and 16 times more expensive than rail transportation.

An overview of the quality of services offered by transportation modes used in this article can be seen in Table 1. 
INDEPENDENT JOURNAL OF MANAGEMENT \& PRODUCTION (IJM\&P)

http://www.ijmp.jor.br

v. 7, n. 5, Special Edition IFLOG 2015

ISSN: 2236-269X

DOI: 10.14807/ijmp.v7i5.459

Table 1: Relative ranking of modes of air transportation and water transport by cost and operations performance characteristic

\begin{tabular}{|c|c|c|c|c|c|}
\hline \multirow{2}{*}{$\begin{array}{c}\text { Transportation } \\
\text { mode }\end{array}$} & \multirow{2}{*}{$\begin{array}{c}\text { Cost } \\
1=\text { major }\end{array}$} & \multirow{2}{*}{$\begin{array}{c}\text { Average } \\
\text { delivery time } \\
1=\text { faster }\end{array}$} & \multicolumn{2}{|c|}{ Variability of delivery time } & \multirow{2}{*}{$\begin{array}{l}\text { Losses and } \\
\text { Damage } \\
1=\text { minor }\end{array}$} \\
\hline & & & $\begin{array}{l}\text { Absolute } \\
1=\text { menor }\end{array}$ & $\begin{array}{c}\text { Percentage } \\
1=\text { minor }\end{array}$ & \\
\hline $\begin{array}{l}\text { Water } \\
\text { transport }\end{array}$ & 5 & 5 & 5 & 4 & 2 \\
\hline Air transport & 1 & 1 & 1 & 5 & 3 \\
\hline
\end{tabular}

There are trade-offs among the costs of all logistics activities, but those existing between the inventory maintenance activities and transport worth mentioning the following: transportation costs and inventory maintenance are the major components of logistics costs; the cost of maintaining inventories is one of logistics costs that has grown the most over the years (kator, 2007). Overall, the trade- offs between maintaining inventories and transportation costs stem from the fact that transport influences the time that inventories remain in transit and on site. (BHATNAGA ; TEO , 2009)

The total logistics costs composition is given through sum of inventory costs, storage, purchase and transportation. Carraro (2009) proposed a graphical representation of the total cost logistic curves by adding these elements, the minimum cost is given by the inflexion point of the total cost. This representation can be seen in Figure 1.

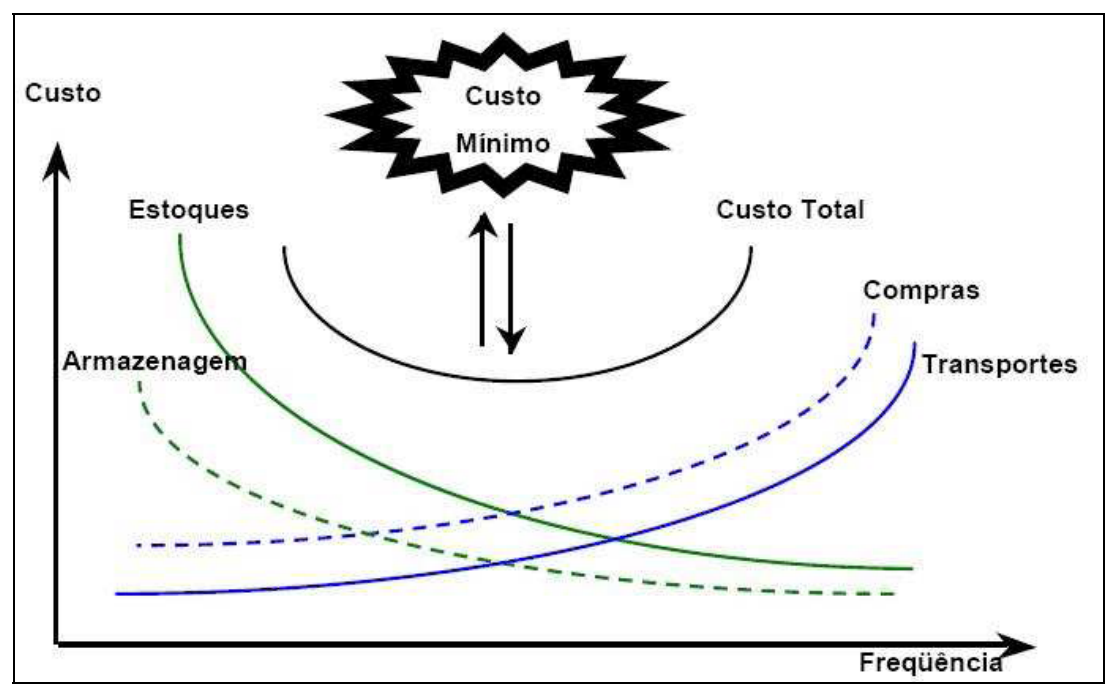

Figure 1: Logistics Total Cost Source: Carraro 2009 .

It can be seen from Figure 1 that with the frequency increase of transportation and purchases elements there is a reduction in the costs of warehousing and 
DOI: $10.14807 /$ ijmp.v7i5.459

inventory elements. The opposite occurs when it reduces the frequency with purchases and transportation, with an increase in the storage and inventory cost.

For Ballou (2006) when a shuttle is not used in order to provide competitive advantage, the best option is the one obtained by offsetting the cost of using a shuttle service to the indirect cost of inventory attached to the selected modal performance.

The next section covers the transportation mode selection through basic compensation cost. In other words, the cost compensation of using the shuttle service to the indirect cost of inventory related to the performance of the modal.

\subsection{Transportation modal selection}

For transportation mode selection were used the following calculations:

\section{Annual cost of transportation (Cta):}

$C t_{a}=D_{a} \times V_{f}$

Where $\mathrm{Da}$ is the annual product demand and $\mathrm{Vf}$ is the freight tariff rate for the used modal

Inventory cost at the source (Ceo):

Ceo $=$ Vmanut $\times$ Vunit $\times\left(\frac{\text { VLentr }}{2}\right)$

Where Vmanut is the storage maintenance per year and Vunit is the product average unit value.

The average inventory on both ends of the distribution channel can be approximated as $\left(\frac{\text { VLentr }}{2}\right)$, where VLentr is the board lot size.

Inventory cost on destination (Ced):

Ced $=$ Vmanut $\times$ Vunit - dest $\times\left(\frac{\text { VLentr }}{2}\right)$

Where Vunit-dest is the avarege unit value of the product on the destination. In other words, it is the average unit value of the product plus the transportation fare. 
DOI: 10.14807/ijmp.v7i5.459

In transit inventory cost (Cet):

Cet $=$ Vmanut $\times$ Vunit $\times \operatorname{Da} \times\left(\frac{\text { Ttrânsito }}{365}\right)$

Where $\mathrm{T}$ is the average transit time in days.

In order to calculate the modal total cost were added to the annual transportation cost and stock costs on the source plus the inventory costs on the destiny and plus the average in transit inventory costs.

$C t \bmod a \mathrm{l}=\mathrm{Cta}+\mathrm{Ceo}+\mathrm{Ced}+\mathrm{Cet}$

\section{METHODS}

This article is characterized by having an exploratory nature with theoretical and used as field work a case study. According to Yin (2010) case study is an empirical inquiry that investigates a contemporary phenomenon in depth and in its real life context, especially when the boundaries between phenomenon and context are not clearly evident.

The case study was carried out in a company that produces machines and parts for industrial cuts solutions and distributes them worldwide. As the object of investigation, it was considered the prism according to which it will develop the research (BEUREN , 2003), it was selected the coolant used to chill torches, because of its importance to customers of this company.

Visits were carried out to study the company to understand its transportation operations. The data used in this work were taken directly from its information system and reports on transportation and the stock maintenance of the product. Data collection was carried out during the month of April 2015.

To determine the best mode of transportation it was used the basic compensation costs model.

\section{CASE STUDY}

This case study was conducted in a medium-sized multinational company that sells metal cutting machines (machines with plasma, laser and water jet technologies) and their spare parts and accessories. All its products are manufactured in the United States and the company distributes them to countries on 
DOI: $10.14807 /$ ijmp.v7i5.459

5 continents, via local offices and central warehouses installed in some countries or directly from the United States.

The company has been operating in Brazil for over 12 years and has an office in the city of Guarulhos in São Paulo. When the company started its activities in the Brazilian market it did not have stocks in the country and served its customers by dispatching the goods directly from the factory located in the United States. In this operating model, the client was responsible for the whole importation process and the goods acquisition process used to take long.

In 2012 a DC was installed in the city of Cajamar in São Paulo, in order to serve customers directly and more efficiently. Since then SKUs (stock keeping unit Inventory Maintenance Unit ) commonly imported, stored and sold in Brazil totaling 1040 items.

The coolant is among the materials sold in Brazil. It is used to cool the torch (piece where the arc plasma used in metal cutting leaves the machine). This fluid prevents the machine overheating, and that a PC board or any component burn or burst due to high temperature. This product is extremely important, because its lack can lead to a production line stop, plus additional costs for replacements of damaged parts due to overheating.

This product consists of $70 \%$ fully treated water and $30 \%$ of chemical components that aid in various parts of the process and also causes slowness in the evaporation. This evaporation is much slower than it would be with water.

Due to impurities that ends up going to the coolant reservoir, this should always be exhausted. Never just complete the level required for the machine good operation. This item has been selected for this study because it has a stable demand since all customers are instructed to exchange it after 500 hours of cutting, which equals about 6 months (depending on the factory working hours).

With the DC installation in the city of Cajamar the company now has space to store lots of coolant. However, the migration of air transportation modal to sea only became feasible with the professionalization of the logistics department.

The logistics department is responsible for conducting the inventory planning taking into account the analysis of demand occurred in the last 13 weeks and 
DOI: 10.14807/ijmp.v7i5.459

received demand forecast by the sales team. This department defines the minimum and maximum inventory levels and enters this data in the ERP (Enterprise Resource Planning - Enterprise Resource Planning ), which in turn sends purchase orders automatically to the United States as the stock level of each item reaches its resupply point.

The freight's amount, as well as the annual stock maintenance cost for this product, the product unit value, the annual product demand, the in-transit time average and delivery batch sizes can be seen in Table 2:

Table 2: Relatives Costs to Company's Transportation and Coolant Stock Maintenance

\begin{tabular}{|c|c|c|c|}
\hline Elements & General & Air & Sea \\
\hline Freight/shipping per box (US\$) & - & 119,83 & 28.00 \\
\hline Annual cost of stock maintenance & $14 \%$ & - & - \\
\hline Unit value of the product (US\$) & 82,04 & - & - \\
\hline Annual product demand (unit) & 11.545 & - & - \\
\hline Traffic time (days) & - & 15 & 38 \\
\hline Size of shipment lot (unit) & - & 100 & 1728 \\
\hline
\end{tabular}

\section{RESULTS AND DISCUSSIONS}

Some simplifying assumptions were adopted for this study:

- Both the supplier and the company are located in places where the distance and the transportation cost to/from the airport are the same as the distance and the cost of transportation to/from the port.

- The systems, facilities and staff necessary to handlings and purchases, and transport packaging will be similar in both modes.

It was used basic compensation costs to calculate the modal total cost. Thus by applying the equations 1, 2, 3, 4 and 5 for air transportation, those are the results:

Annual cost of transportation (air):

$\mathrm{Ct}_{\mathrm{a}}=11545 \times 119,83=1383437,35$

Inventory cost at the source (air):

Ceo $=0,14 \times 82,04 \times\left(\frac{100}{2}\right)=574,28$ 
INDEPENDENT JOURNAL OF MANAGEMENT \& PRODUCTION (IJM\&P)

http://www.ijmp.jor.br

v. 7, n. 5, Special Edition IFLOG 2015

ISSN: 2236-269X

DOI: 10.14807/ijmp.v7i5.459

Inventory cost on destination (air):

Ced $=0,14 \times 201,87 \times\left(\frac{100}{2}\right)=1413,09$

$\underline{\text { In transit inventory cost (air): }}$

Cet $=0,14 \times 82,04 \times 11545 \times\left(\frac{15}{365}\right)=5449,37$

Modal total cost (air):

$C t \bmod a l=1383437,35+574,28+1413,09+5449,37=1390874,09$

Applying the equations $1,2,3,4$ and 5 for shipping it gets the following results:

Annual cost of transportation (sea):

$\mathrm{Ct}_{\mathrm{a}}=11545 \times 28,00=323260,00$

Inventory cost at the source (sea):

Ceo $=0,14 \times 82,04 \times\left(\frac{1728}{2}\right)=$

Inventory cost on destination (sea):

Ced $=0,14 \times 110,04 \times\left(\frac{1728}{2}\right)=13310,44$

$\underline{\text { In transit inventory cost (sea): }}$

Cet $=0,14 \times 82,04 \times 11545 \times\left(\frac{38}{365}\right)=13805,06$

Modal total cost (sea):

$C t \bmod a l=323260+9923,56+13310,44+13805,06=360299,06$

The transportation costs synthesis, for both transportation modes can be seen in Table 3. 
INDEPENDENT JOURNAL OF MANAGEMENT \& PRODUCTION (IJM\&P)

http://www.ijmp.jor.br

v. 7, n. 5, Special Edition IFLOG 2015

ISSN: 2236-269X

DOI: 10.14807/ijmp.v7i5.459

Table 3: Company's Transportation Costs in the Importation of coolant

\begin{tabular}{|c|c|c|}
\hline Costs & Air (US\$) & Maritime (US\$) \\
\hline Annual cost of transport (Cta) & $1.383 .437,35$ & $323.260,00$ \\
\hline Inventory cost at source (Ceo) & 574,28 & $9.923,56$ \\
\hline Inventory cost in destination (Ced) & $1.413,09$ & $13.310,44$ \\
\hline Stock cost in transit (Cet) & $5.449,37$ & $13.805,06$ \\
\hline Total cost of the modal (Ctmodal) & $1.390 .874,09$ & $360.299,06$ \\
\hline
\end{tabular}

It is possible to check that the most advantageous mode of transportation for importing coolant from the US is the maritime.

It is also possible to identify that for this product the cost reduction of approximately $74 \%$ in transportation costs by switching the transportation mode from air to maritime.

The results corroborate with Lorandi, Bertan and Ferreira's (2011) research and with the literature claiming that air transport is more suitable for high-value and low volume products, however the coolant has a low value (US \$ 82.04) and a large annual importation volume (11545 units).

The study contributed to the theme of using the basic compensation cost, which in this study was effective for the transportation mode selection.

\section{FINAL CONSIDERATIONS}

This paper aims to select the mode of transport able to minimize total costs in the import by using the basic compensation cost. The cost compensation of use the shuttle service to the indirect cost of inventory related to performance modal. The results showed that it is advantageous to replace the air mode by maritime shipping in the coolant importation.

It may be important to mention that the use of shipping requires a better accompaniment from logistics department, which should better monitor sales and forecast demand, making sure to have this item in stock. Despite the results presented, the transportation decisions need to be accompanied often, after all no process is static and the involved variables can be modified by it in a way that the transportation mode selected today becomes a no better option tomorrow. 
DOI: 10.14807/ijmp.v7i5.459

The paper contributed from a theoretical and practice manner that held a practice application of modal selection, helping on the company's decision on transportation mode substitution.

As it comes to limitations, it is possible to point, basically, the difficulty of generalize from a case study. This paper was limited only to study air and maritime transportation modes due to the geographical position of both supplier and customer/buyer and the accessibility of other modes for both of them.

New studies will be done for other products sold by this company in order to accomplish the analysis of all items that it imports and commercializes in Brazil for the purpose of selecting the most adequate transportation mode.

\section{REFERENCES}

AGUIAR, M. S. (2011) Análise de alternativas do transporte multimodal de cargas manufaturadas destinadas à exportação. Dissertação (Mestrado). Universidade Federal de Itajubá. Itajubá. 103p.

ALVARENGA, A. C.; NOVAES, A. G. N. (2004) Logística aplicada: suprimento e distribuição física. $3^{\mathrm{a}}$.ed. - São Paulo: Edgard Blucher.

BALLOU, R. H. (2006) Gerenciamento da cadeia de suprimentos/logística empresarial. $5^{a}$ ed. - Porto Alegre: Bookman.

BEUREN, I. M. (2006) Como Elaborar Trabalhos Monográficos em Contabilidade: Teoria e Prática. $3^{\mathrm{a}}$.ed - São Paulo: Atlas.

BHATNAGAR, R.; TEO, C. C. (2009) Role of logistics in enhancing competitive advantage: a value chain framework for global supply chains. International Journal of Physical Distribution \& Logistics Management. Bradford, v. 39, n. 09, p. 202226.

BOWERSOX, D. J.; CLOSS, D. J. (2001) Logística empresarial: o processo de integração da cadeia de suprimento. São Paulo: Atlas.

CAIXETA-FILHO, J. V.; GAMEIRO, A. H. (2001) Transporte e logística em sistemas agroindustriais. $1^{a}$ ed. São Paulo: Atlas.

CARRARO, P. R. (2009) Avaliação da Influência de Aspectos Logísticos, Fiscais e Ambientais no Projeto de Redes de Distribuição Física. 145 f. Dissertação (Mestrado em Engenharia de Sistemas Logísticos) - Universidade de São Paulo, São Paulo, 2009.

CEPER. Boletim do Comércio Exterior: Disponível em: <http://www.fundace.org.br/_up_ceper_boletim/ceper_201411_00098.pdf>. Acesso em: 17 de out 2015.

CHOPRA, S.; PETER, M. (2003) Gerenciamento da cadeia de suprimentos: estratégia, planejamento e operação. São Paulo: Pearson Prentice Hall. 
CHOW, G. (2008) Getting back to basics. Canadian Transportation Logistics. Don Mills, v. 111, n. 10.

FARIA, A. C.; COSTA, M. F. G. (2010) Gestão de custos logísticos. $1^{\text {a }}$ ed - São Paulo: Atlas.

KATOR, C. (2007) Inventory costs rise dramatically. Modern Materials Handling: Warehousing Management Edition. Framingham, v. 62, n. 07.

NOVAES, A. G. (2007) Logística e gerenciamento da cadeia de distribuição: estratégia, operação e avaliação. $3^{a}$. ed -. Rio de Janeiro: Elsevier.

RODRIGUES, P. R. A. (2007) Introdução aos Sistemas de Transporte no Brasil e à Logística Internacional. $4^{\mathrm{a}}$ ed - São Paulo: Aduaneiras.

SALGADO, L. H.; VASSALLO, M.; OLIVEIRA, A. (2010) Regulação, Políticas Setoriais, Competitividade e Formação de Preços: Considerações sobre o Transporte Aéreo no Brasil. Revista de Literatura dos Transportes, v. 4, n. 1, p. 748

SILVA, C. F.; PORTO, M. M. (2003) Transportes e Seguros e a Distribuição Física Internacional de mercadorias. São Paulo: Aduaneiras.

YIN, R. K. (2010) Estudo de caso: planejamento e métodos. $4^{\mathrm{a}}$ ed - Porto Alegre: Bookman. 